\title{
KONOTACJE WARTOŚCIUJĄCE W ODAPELATYWNYCH NAZWISKACH MIESZKAŃCÓW ŚLĄSKA CIESZYŃSKIEGO (XIX WIEK)
}

\section{WPROWADZENIE}

Śląsk Cieszyński jako obszar pogranicza historyczno-geograficznego i kulturowego obrazuje specyficzny dla tego subregionu system wartości. Aksjologiczny wymiar tego terytorium ukształtowały: naturalne położenie (topografia), historyczne uwarunkowania, związane ze zmianami przynależności państwowej, oraz nasilające się w XIX wieku ruchy migracyjne ludności z różnych regionów. Czynniki te, tworzące sieć wzajemnych powiązań, ukształtowały $\mathrm{w}$ dziejowym procesie swoisty dla Ziemi Cieszyńskiej ${ }^{1}$ zasób onimiczny. Regionalna odmienność zasobu nazwisk mieszkańców Śląska Cieszyńskiego, wyróżniającego się odrębną specyfiką językową spośród subregionalnych wspólnot komunikacyjnych na Śląsku (por. Wyderka 2005: 64-65), wyraża się w niejednolitych pod względem językowego pochodzenia podstawach apelatywnych translokowanych do sfery onimicznej. Owo zróżnicowanie odnosi się do sposobów tworzenia nazwisk równych apelatywom (bez wykładników formalnych) oraz do formacji derywowanych, pomnażanych w postaci motywacyjno-strukturalnych modeli nazewniczych. Immanentność w zakresie użycia substratu gwarowego jako komponentu nazwisk opisywanego typu ukazuje istotę procesu asymilacji rdzennej ludności Śląska Cieszyń-

\footnotetext{
1 Używając terminu Ziemia Cieszyńska, ma się na myśli „ziemie, które zawsze należały do Śląska, czyli nie były nigdy przecinane żadnymi granicami" (Pysiewicz-Jędrusik, Pustelnik, Konopska 1998: 47-48).
} 
skiego z ludnością napływową, jak również obrazuje zjawisko przenikania się gwar jako wynik koegzystencji różnych odmian językowych oraz (sub)regionalnych kultur.

Uwzględniając przywołane determinanty, można stwierdzić, że właściwości wartościujące zawarte $\mathrm{w}$ apelatywach nazwisk badanego obszaru odsłaniają schematy myślowe człowieka ${ }^{2}$ oraz pewien typ schematów kulturowych ludzi żyjących w południowo-wschodniej części Śląska $\mathrm{w}$ epoce nowopolskiej i w wiekach poprzednich. Wychodząc zaś z założenia, że analiza nazwisk pozwala wskazać na model wartościowania właściwy danej mikrowspólnocie regionu (por. Kaleta 2003: 21-48, Dacewicz 2003: 11-19; Rzetelska-Feleszko 2006: 591-599; Matusiak-Kempna 2010: 355-363; Bogdanowicz 2010: 115-125) i odwołując się do twierdzeń Ryszarda Tokarskiego, por. „Językowy obraz świata powstaje nie tylko w relacji rzeczywistość pozajęzykowa - język, lecz także jako następstwo przynależności człowieka, twórcy języka do określonego kręgu kulturowego oraz obowiązujących w tej kulturze ideałów dobra i piękna" (Tokarski 2001a: 369), w niniejszym artykule uwagę poświęca się wybranym typom rodzimych odapelatywnych (niederywowanych) nazwisk mieszkańców Śląska Cieszyńskiego, wyekscerpowanych z dziewiętnastowiecznych materiałów źródłowych ${ }^{3}$. Owe nazwiska stały się źródłem poszukiwań regionalnych znaczeń ${ }^{4}$ i regionalnego systemu wartości ${ }^{5}$, konotującego swoisty typ oceny ludzi i ich postaw.

2 Teoria językowego obrazu świata E. Sapira oraz B.L. Whorfa dotyczy wzajemnej relacji, jaka istnieje pomiędzy językiem oraz myśleniem a rzeczywistością (Worf 1982).

3 Podstawę materiałową stanowią księgi metrykalne przechowywane w Parafii Rzymskokatolickiej św. Marii Magdaleny w Cieszynie oraz w Parafii Ewangelicko-Augsburskiej w Cieszynie, jak również rozmaite dokumenty gromadzone w Archiwum Państwowym w Katowicach Oddział w Cieszynie. Zbiór ten liczy kilkadziesiąt ksiąg oraz innych rękopiśmiennych materiałów historycznych, mających tytuły łacińskie.

4 Zaproponowany podział nazwisk stanowiących przedmiot opisu, który uwzględnia kryterium znaczeniowe, stworzono ze świadomością leksykalnej polimotywacyjności nazw pospolitych motywujących nazwiska, biorąc tym samym pod uwagę możliwości różnej ich interpretacji oraz klasyfikacji. Najbardziej prawdopodobne etymologie nazwisk, wyodrębniono na podstawie kilkunastu dostępnych słowników. Ich wykaz podano na końcu tekstu. W analizie nazwisk kierowano się zmodyfikowaną klasyfikacją zaproponowaną przez Stanisława Rosponda (Rospond 1967: 15-17).

5 Za J. Puzyniną termin wartościowanie interpretuję jako: „czynność psychiczną człowieka, polegającą na stwierdzeniu, jakie (i w jakim stopniu) wartości pozytywne lub negatywne właściwe są - zdaniem osoby wartościującej - danym cechom, zachowaniom, a pośrednio przedmiotom" (Puzynina 1992: 83). 
Biorąc pod uwagę, że nazwiska odapelatywne są uznane za asemantyczne, odniesiono się do możliwości opisu motywujących je podstaw wskazujących m.in. na ważne dla mikrowspólnoty desygnaty. J. Apresjan podkreśla, że zawarte $w$ desygnatach elementy wartościujące są odbiciem wyobrażeń kulturowych i tradycji związanych z daną jednostką wyrazową. Poszczególne elementy wartościujące uaktywniają się w określonych sytuacjach komunikacyjnych - uzupełniają i wzbogacają znaczenie podstawowych jednostek wyrazowych, które mogą wywoływać u odbiorców swoiste asocjacje kulturowe (Apresjan 2000: 76). Konotacje ${ }^{6}$ uznawane za elementy pragmatyki, wpisane $\mathrm{w}$ semantykę nazw pospolitych realizujących swe funkcje $\mathrm{w}$ obrębie określonego typu i charakteru sytuacji komunikatywnych, sprawiają, że nazwiska odapelatywne nabierają dla użytkowników języka (ich twórców) treści wartościujących, co wynika ze skojarzeń z motywującym je wyrazem pospolitym (Bogdanowicz 2010: 124) 7 .

Podejmując się próby analizy zebranego materiału antroponimicznego, odniesiono się do semantyki aksjologicznej rozwijającej się w ramach nurtu kognitywnego. Opisując typy motywacyjne nazwisk oraz proces ich tworzenia się (por. m.in.: Górny 2003: 231-239; Rutkowski 2005: 99-110), odwołano się do metody pól znaczeniowych. Interpretując zebrany zasób nazwisk odapelatywnych, uwzględniono też socjolingwistyczny aspekt nazewnictwa oraz odwołano się do badań statystycznych.

Analizowany tu materiał obejmuje 761 rodzimych nazwisk odapelatywnych, które nie zawierają formalnych wykładników nazwiskotwórczych. Nazwiska powstałe od przezwisk charakteryzujących stanowią $6,7 \%$ całości zgromadzonych nazwisk cieszyńskich ${ }^{8}$ (zawierających również nazwiska o obcej genezie); substrat gwarowy, pochodzący z różnych polskich dialektów reprezentuje $47,6 \%$ analizowanych tu nazwisk (362 jednostki leksykalne); geneza pozostałych 399 nazwisk genetycznie wywodzi się od apelatywów funkcjonujących w języku ogólnonarodowym; 75 nazwisk motywowanych było słownictwem staropolskim.

6 Terminy konotacja, asocjacja i skojarzenie traktowane są tutaj jako określenia synonimiczne.

7 Por. „Użytkownik języka dostrzega w nazwie własnej na zasadzie silnie odczuwanych zależności motywacyjnych między wyrazami fundującymi a nazwami pewną treść pojęciową i sądzi, że częściowo lub w całości przechodzi ona na denotat nazwy" (Bogdanowicz 2000: 118-119).

8 Zebrany zasób nazwisk mieszkańców Cieszyna i okolic zawiera 11231 jednostki, z których 4491 zaklasyfikowano jako odapelatywne. 
Uwzględniając przypisane analizie cele interpretacyjne ${ }^{9}$, jak również nawarstwiające się determinanty współuczestniczące w kreacji onimicznej, zgromadzony materiał zaklasyfikowano do nadrzędnej kategorii semantycznej Nazwiska odapelatywne charakteryzujace wyglad zewnętrzny $i$ charakter człowieka. W obrębie tego nadrzędnego pola znaczeniowego rozróżniono cztery szczegółowe grupy (klasy) nazwisk należących do skonkretyzowanych podgrup danego pola znaczeniowego, ewokujących kulturowy typ konotacji semantycznych ${ }^{10}$ o szerokiej gamie cech fakultatywnych, por.: a) Nazwiska pochodzące od określeń człowieka, od nazw części ciała i ubioru; b) Nazwiska pochodzace od nazw roślin i zwierząt; c) Nazwiska pochodzace od nazw zjawisk przyrodniczych, atmosferycznych i nazw temporalnych; d) Nazwiska od nazw dźwiękonaśladowczych. Nazwiska opisywanej kategorii wraz z wymienionymi podgrupami obejmują 761 form (to jest $45,7 \%$ całości zgromadzonych nazwisk odapelatywnych bez wykładników formalnych).

Najliczniejszą grupę opisywanych nazwisk reprezentują te, które indywidualizowały człowieka bezpośrednio za pomocą znaczenia leksykalnego wyrazu pospolitego, przywołującego określony sposób wartościowania (zwłaszcza o nacechowaniu pejoratywnym). Większość z nich opisywała cechy psychiczne człowieka - jego charakter, osobowość, przyzwyczajenia i nawyki, oraz wygląd zewnętrzny, a zwłaszcza - ułomności.

9 Do nadrzędnych celów zalicza się m.in.: możliwość odkrycia zakodowanych w nazwiskach wartości konotowanych przez podłoże apelatywne, zilustrowanie zjawiska oddziaływania na siebie gwar, ujawnianego przez synonimię w gwarach, i odwrotnie różnicowania się w obrębie jednej gwary znaczenia leksykalnego identycznej formalnie jednostki leksykalnej, ukazanie typów nominacji (bezpośredniej i pośredniej) nazw odapelatywnych w procesie kreacji nazw o charakterze wartościującym oraz prezentację mechanizmów tworzenia i funkcjonowania tych nazwisk w społecznym obiegu.

10 Por. R. Tokarski: „Konotacje semantyczne [...] pokazują subiektywizm myślenia człowieka, wykorzystują kryteria wartościowania świata” (Tokarski 1998: 52); też: „Konotacja semantyczna jest składnikiem treściowym bardzo płynnym, warunkowanym kontekstowo, związanym z niektórymi tylko użyciami słowa czy aktualizowanym w niektórych tylko użyciach" (Tokarski 1998: 51). Silne osadzenie jednostek językowych (nazw pospolitych) w kulturze powoduje, że są one podstawą wykształcenia konotacji. Wyekscerpowany materiał $\mathrm{w}$ postaci nazwisk odapelatywnych umożliwił wykrycie zawartych w ich podstawach konotacji oceniających (utrwalonych w społecznym obiegu), a zwłaszcza tych ekspresywnych (deprecjonujących człowieka), oraz konotacji okazjonalnie wartościujących, powstałych wskutek konotacji indywidualnych i zbiorowych o różnym stopniu utrwalenia i uszczegółowienia. 


\section{ANALIZA NAZWISK ODAPELATYWNYCH}

\section{NAZWISKA POCHODZĄCE OD OKREŚLEŃ CZŁOWIEKA, OD NAZW CZĘŚCI CIAŁA I UBIORU}

Nazwiska zaklasyfikowane do grupy (a) reprezentuje 360 form obejmujących $21,4 \%$ całości niederywowanych nazwisk o podłożu apelatywnym; 232 z nich określa stany psychiczne człowieka, zaś 132 opisuje jego wygląd zewnętrzny. Ta grupa nazwisk jednoznacznie obrazuje akt wartościowania człowieka - spostrzeganie go w rozmaitych (kon)sytuacjach, oraz jego ocenę (z dominacją konotacji ujemnych).

W grupie nazwisk motywowanych nazwami pospolitymi wywodzącymi się z polszczyzny staropolskiej (21 form) lub z gwary (158 form) przeważają nazwiska o zabarwieniu negatywnym ${ }^{11}$. Znaczenia apelatywów motywujących nazwiska umożliwiły przyporządkowanie ich do kilku pól tematycznych, związanych z takimi wybranymi cechami ludzkimi, jak: impulsywność i konfliktowość (por.: Burda (30) ${ }^{12}<$ stp. burda 'awanturnik, zawadiaka', Kręcioch (6) < gw. śl. kręcioch 'człowiek afektowany', Warzecha (9) < gw. ciesz. warzecha przen. 'człowiek wszczynający zwadę, plotkarz, krętacz', też 'warząchew', Rykała (8) < gw. młp. rykała 'awanturnik'), ograniczoność umysłową (por.: Dubiel (1) < stp. dubiel 'głupiec', też 'gatunek ryby', Hanak (21) < gw. śl. hanak 'człowiek tępy, głupi'), pychę i zarozumiałość (por.: Herny (3) < gw. śl. i gw. młp. < stp. herny 'pyszny, duszny', Mędroch (9) < gw. ciesz. mędroch 'mędrek, mądrala'), stręczycielstwo i dokuczliwość (por.: Koczot (1) < stp. koczot 'stręczyciel', też < gw. młp. 'kogut', Bździoch (1) < gw. młp. bździoch 'plotkarz, głupiec'),

11 Od wyrazów używanych w polszczyźnie ogólnej wywodzą się 54 nazwiska opisujące stany psychiczne człowieka. Większość z nich, przybierając charakter metaforyczny, konotuje cenione społecznie wartości typu: skromność, dobroduszność, łagodność, pracowitość, mądrość, niepodatność na wpływy, zdyscyplinowanie i odwagę (por. nazwiska z tej grupy o najwyższej frekwencji: Cichy (194) < cichy, Prymus (29) < prymus i Twardy (59) $<$ twardy 'nieugięty; niepodatny na wpływy'). Obok nich istnieje także zestaw nazwisk motywowanych określeniami pejoratywnymi (o niskiej frekwencji), wskazującymi na temperament, głupotę, nieporadność oraz obżarstwo człowieka (por.: Chytry $(1)<$ chytry, Duraj (8) < duraj 'głupiec', Dziki (1) < dziki, Gamoń (2) < gamoń, Mruk (3) < mruk, Szalony (1) $<$ szalony, Żartok (31) < żarłok).

12 Nazwiska przywoływane jako materiał egzemplifikacyjny wprowadza się do tekstu wedle schematu: nazwisko (zapisane kursywą), w okrągłym nawiasie podano jego frekwencję, następnie (kursywą) wskazano wyraz (apelatyw) motywujący nazwisko, w łapkach zaś - znaczenie motywującej nazwisko nazwy, por.: Merchel $(1)<$ gw. kasz. marchel pogardl. 'za młody do roboty'. Kwantyfikator < oznacza pochodzenie. 
niezdarność i nieporadność życiową (por.: Cielepa $(1)<$ gw. ciesz. i gw. śl. cielepa 'niedołęga, ciemięga, fajtłapa, gapa', Macek $(1)<$ gw. ciesz. macek 'niezdara, niedołęga, człowiek niezaradny', też 'palec', 'ciemność', Pita (1) < gw. śl. pita przen. 'nieudacznik', też 'vulva', a w gw. kasz. 'pijak')13.

$\mathrm{Z}$ analizy nazwisk charakteryzujących bezpośrednio wynika również, że krytycznie podchodzono do nawyków ludzkich - pijaństwa i obżarstwa, por.: Koterba (3) < gw. śl. koterba 'człowiek, który coś wypił', $<$ gw. ciesz. i gw. śl.: Jedzok (64) < jedzok 'lubiący jeść' i Żyrok (1) < żyrok 'żarłok'.

Wśród nazwisk z grupy (a) na uwagę zasługują te, w których potępiano negatywny stosunek ludzi do pracy, uzewnętrzniany poprzez takie cechy, jak: próżność, lenistwo i partactwo, uniemożliwiające efektywne zaangażowanie się w wykonywanie obowiązków, por.: Kojan (1) < stp. kojan 'nicpoń', < gw. ciesz.: Bisaga (2) < bisaga 'leń, nicpon', Lump (6) < lump 'gałgan, nicpon, łajdak, łobuz', Skrymba (1) < skrymba 'len', Mader (4) < gw. śl. mader 'partacz wiejski', Tyron (1) < gw. młp. tyron 'marnotrawca'.

Do nielicznych przykładów nazwisk, które pochodzą od określeń człowieka i ukazują nazywaną nimi osobę w pozytywnym świetle, można zaliczyć formy urabiane wyrazami używanymi już w staropolszczyźnie (por.: Jonak (1) 'zuch', Pokorny (15) 'uległy', Szczęsny (6) 'szczęśliwy') oraz wyrazami żywotnymi w gwarach śląskich (por.: Hojny (1) < hojny 'szczodry', Promny (1) < promny 'wyborny, przedni'), zwłaszcza zaś w ich cieszyńskiej odmianie (por.: Lepszy (2) < lepszy 'stopnień wyżej od dobry', Milaczek (16) < milaczek 'ulubieniec', Posłuszny (9) < stp. 'uległy', Prawy (1) $<$ stp. prawy 'prawdziwy', też 'sprawiedliwy', Procny (2) < procny 'pracochłonny, żmudny', Wiesioły (9) < stp. wiesioły 'wesoły').

Troskę o drugiego człowieka - chorego, słabego oraz nieporadnego ujawnia kilkanaście odapelatywnych nazwisk, por.: Nieborak $(1)<$ nieborak, Staby (2) < słaby, Smutny (17) < smutny, Golec (33) < golec 'nagus', też 'biedak', 'łysy', 'cymbał, drągal', Sagon (19) < gw. ciesz. i gw. śl.

13 Krytykowano też: oszustwo, kłamstwo i krętactwo (por.: Szybała (1) < stp. szybała 'oszust', Wywijas (1) < gw. wlkp. i gw. Pom. Pd. 'krętacz, kłamca, łgarz'), gadulstwo i zrzędliwość (por.: Rajca (1) < gw. śl. i gw. młp. rajca 'gaduła', też < gw. maz., gw. kasz. i gw. Pom. Pd. 'swat', Molenda (10) < gw. ciesz. molynda [pochylenie samogłoski e] 'człowiek zanudzający mówieniem, dążący do swojego ukrytego celu'), dewocję (por. Bożek (3) < stp. 'nabożniś'), flegmatyczność (por. Depta $(1)<$ gw. śl. depta 'guzdrała'), uległość (por. Hatlapa (2) < gw. śl. hatlapa 'człowiek uległy') oraz pochlebstwo i samochwalstwo (por. Ligęza (3) < stp. 'człowiek lubiący się przymilać', Hubek (1) < gw. śl. hubek 'samochwała'). 
sagoń 'nagus, golas', Boroczek (1) < gw. ciesz. boroczek 'biedaczek', Chudzioczek (5) < gw. ciesz. chudzioczek i Chudziok (1) < gw. ciesz. chudziok 'biedactwo, biedaczek', Bździna (1) < gw. młp. bździna 'człowiek bezsilny, słaby', Żmuda (8) < gw. młp. żmuda 'mitręga, człowiek słaby, mizerny', też $<$ stp. 'nudziarz', < gw. śl. 'trud, strata czasu'.

Niektóre wyrazy nabywają konotacji poprzez aluzję do realiów kulturowych (Monteiro-Platin 2011: 249-275), inne zaś odnoszą się do konceptów kulturowych. Te tendencje poświadcza m.in. zbiór nazwisk nacechowanych ekspresywnie, do tworzenia których użyto nazw wyrażających stosunek do "swoich" i „obcych”, por.: Stela (1) < gw. ciesz. stela 'stąd' - określenie autochtoniczne oraz Owen (1) < gw. maz. owen 'tamten' w znacz. 'obcy', Nowak (359) < nowak 'człowiek nowy w zawodzie, miejscowości, religii', Nowotny (5) < gw. młp. < stp. nowotny 'człowiek nowy $\mathrm{w}$ danym środowisku', też 'człowiek, który przyjął nową wiarę', zaś w gw. młp. i gw. kasz. 'nowoczesny', Przybyła (2) < gw. ciesz. przybyła 'przybysz', Świeży (1) < świeży 'nowy'.

Rejestr nazw motywujących nazwiska z grupy znaczeniowej (a) dopełniają formy opisujące wygląd zewnętrzny człowieka (są to 142 jednostki). Szczegółowy ogląd tych nazwisk odsłania mechanizmy kreacyjne. Ich analiza pozwala wskazać wielokrotnie przywoływane pola semantyczne, konotujące określony typ wartości. Dominują wśród nich określenia pochodzące od przezwisk utworzonych za pomocą metafory lub metonimii, znaczeniowo odnoszące się do człowieka wysokiego, do człowieka o rudych włosach bądź do człowieka ułomnego. Określenia te można zestawić ze sobą na zasadzie opozycji: niski/wysoki, szczupły/otyły, atrakcyjny fizycznie/ułomny, człowiek o ciemnym/jasnym kolorze skóry. Nazwiska, które wywodzą się od nazw powiązanych z oceną człowieka i odnoszących się do wzrostu lub tężyzny fizycznej, są najliczniej reprezentowane, por.: Wielkus $(20)<$ gw. ciesz. wielkus 'człowiek wysokiego wzrostu', Bizoń (11) < gw. młp. bizoń 'chłop wielki, niezgrabny'. Można je zestawić antonimicznie z nazwiskami: Mały (2) < mały, Guzy (1) < stp. guzy 'karłowaty', Mężyk (1) < stp. mężyk 'karze1', Malik (74) $<$ gw. ciesz. malik 'ktoś mały, niedorosły', też < gw. młp. 'choroba koni i wołów', Kluk (1) < gw. ciesz. i gw. śl. pogardl. 'mały chłopiec' (2), Chudziec (1) < chudziec 'chudy', Suchy (11) < suchy 'szczupły, chudy, wychudzony', Masny 1) < gw. ciesz. masny 'tłusty, mięsisty', Kalemba (3) < gw. śl. kalemba 'ociężała kobieta'. Równie często w nazwiskach odapelatywnych utrwalono nazwy eksponujące mankamenty urody oraz ułomności czło- 
wieka, por.: Bałon (2) < bałoń [alternacja $n:$ n] 'ktoś o wyłupiastych oczach', Halacz (6) < gw. śl. halacz 'na Śląsku - człowiek z wybałuszonymi oczyma', Zębaty (3) < gw. młp. zębaty 'człowiek mający duże zęby', Chromy (24) $<$ stp. chromy 'kulawy', Halama (70) < gw. śl. halama 'człowiek niezgrabny', też 'prostak', Kulas (2) < gw. śl. kulas 'kulawy', Kulfa (5) < gw. góral. kulfa 'osoba krzywa', też 'prostak'. Część z nazwisk asocjacyjnie odnosi się do powtarzalnych czynności o charakterze nawykowym, por.: Rojda (2) $<$ rojda 'brzydko chodzić', Mrugała (114) < gw. śl. mrugała 'ten, kto często mruga', też < stp. 'oszust porozumiewający się przez mruganie; dający mruganiem znaki'. Nieliczne w tej grupie są nazwiska podkreślające urodę człowieka (por.: stp. Krasny (2), Piekny (4) < gw. ciesz. i gw. młp. < stp. piekny 'piękny', Szwarny (1) < szwarny 'piękny') oraz opisujące zalety człowieka (por.: Jawien (1) < stp. 'okazały, wydatny', Strojny (1) < stp. 'składny, proporcjonalny'). Bezpośrednie odwołanie się do konkretnych cech wyglądu ujawniało się też przy pomocy kreacji metonimicznych, por.: Kędzior (9) < kędzior 'lok kędzierzawy', Chlupaty (3) < gw. ciesz. chtupaty 'człowiek kosmaty, włochaty, mający długie włosy' < czes. chlupatý 'człowiek kudłaty', Fusek (26) < gw. ciesz. fusek 'wąsik', Ryży (1) < ryży 'rudy', Rudek (1) < stp. rudek 'człowiek o rudych włosach', Rydzy (2) < stp. rydzy 'rudy', Ryszawy (2) < gw. ciesz. ryszawy < czes. ryšavý 'rudy', Szafraniec (1) < stp. szafraniec 'człowiek o rudych włosach'14, Burek (4) < burek 'szary', Siwy (100) < siwy, Szary (6) < szary. Do opisu koloru ciała człowieka użyto kilku określeń (warto zwrócić uwagę na ich frekwencję), jak: Branny $(162)<$ gw. ciesz. branny 'opalony, ogorzały', też 'o maści konia gniady', Brudny (246) < brudny 'człowiek o ciemnej karnacji', Oczadły (11) 'okopciały, oczadziały, opalony'.

W nazwiskach pochodzących od określeń człowieka, przyporządkowanych do grupy znaczeniowej (a), w deprecjonujący sposób oceniano niechlujstwo człowieka, por.: Ciompa (64) < gw. ciesz. ciómpa 'nieodpowiednio, niechlujnie ubrana kobieta', Mazok (4) < gw. ciesz. mazok 'brudas', też $<$ gw. śl. 'beksa', Mazula (2) < gw. śl. mazula 'brudna kobieta', Kidoń (9) $<$ gw. śl. kidon 'człowiek niechlujny, niezaradny'.

$14 \mathrm{~W}$ kulturze istnieje stereotyp, że człowiek o rudych włosach jest dwulicowy, złośliwy i przebiegły, lubi manipulować innymi; również przynosi pecha. Stereotyp ten można również skojarzyć z powiedzeniem: chytry jak lis, mającym prawdopodobnie związek z lisią fizjonomią. W wypadku tego i innych stereotypów powierzchowna obserwacja prowadzi do nieprawdziwych, często krzywdzących wniosków, przyczyniając się do negatywnego wartościowania nosiciela nazwy. Por. Matusiak 2007: 379-389. 
Tworząc kolejny typ nazwisk bezpośrednio charakteryzujących wygląd zewnętrzny człowieka (konotujących pejoratywne skojarzenia), odwoływano się do nazw części ciała ${ }^{15}$, por.: Haręza (1) < stp. haręża 'żołądek', Kika (1) < stp. kika 'kikut', Kotyrba (2) < stp. kotyrba i czes. kotrba pejor. 'łeb', Liczko (3) < stp. liczko 'twarzyczka', Spina (4) < stp. spina 'plecy', Strum (1) $<$ stp. strum 'wole u gardła', Śladek (3) < stp. śladek 'tylna cześć ciała człowieka; pośladek', Czepanek (1) < gw. ciesz. czepanek 'pogardliwie o głowie', Mańdok (10) < gw. ciesz. mańdok 'człowiek leworęczny', Nochol (1) < gw. ciesz. nochal 'wydatny nos', Połykacz (4) < gw. ciesz. połykacz 'przełyk', Wańtuch (1) < gw. ciesz. wańtuch 'wydatny brzuch', Kulsza (2) < gw. maz. i gw. młp. kulsza 'biodro', Pitak (2) < gw. młp. pitak 'grdyka'.

Do bezpośredniej charakterystyki człowieka posłużyły też nazwy ubrań (w tym nazwy: okryć głowy, obuwia i dodatków do ubrań; wynotowano 48 nazwisk tego typu) i nazwy ozdób (jedno nazwisko). Spora część tych nazwisk zawiera $\mathrm{w}$ swych podstawach wyrazy znane już w staropolszczyźnie, por.: Bura (21) < bura 'opończa', Janczyk (1) < janczyk 'rodzaj czapraka', Stula (2) < stula 'chusta, rańtuch', Kreza (1) < kreza 'marszczony, fałdowany kołnierz', Kordon (3) < kordon 'sznurek przy ubraniu wojskowym' lub określenia wywodzące się z różnych odmian gwarowych języka, por.: Brunclik (4) < gw. ciesz. brunclik 'część stroju góralskiego', Janczary (2) < gw. ciesz. janczary 'zużyte buty robocze', ̇̇urek (26) < gw. śl. żurek 'chustka związana w specjalny sposób na głowie mężatki', Kabot $(78)<$ gw. ciesz. i gw. śl. < stp. kabat 'stary płaszcz', Mantel (7) < gw. śl. i gw. ciesz. < stp. mantel 'płaszcz', Ryszka (6) < gw. śl. i gw. młp. ryszka 'falbana', też 'krowa pstrokata', Misiura (6) < gw. młp. < stp. misiura 'czapka bez daszka' oraz Paciorek (9) < paciorek 'koralik'16. Nazwiska te mogły informować o pochodzeniu osoby nazywanej (por. Brunclik 'Góral'), mogły też charakteryzować człowieka modnie ubranego (por.: Koralik, Kreza, Ryszka) bądź określać stan cywilny kobiety (por. Żurek).

15 Typ wartościowania dobry - zły w języku potocznym odzwierciedla się w schematach orientacji przestrzennej odnoszonej do ciała człowieka. Por. pogląd J. Bartmińskiego: ,[...] dobre jest to, co w górze, z przodu i z prawej strony, złe to, co na dole, z tyłu, z lewej strony - odpowiednio do potrzeb i odczuć normalnego człowieka, który porusza się do przodu, chodzi z głową do góry i posługuje się prawą ręką" (Bartmiński 2001: 125).

16 Por. np. Rzaszewska-Klimas 2015: 173-189. 


\section{NAZWISKA POCHODZĄCE OD NAZW ROŚLIN I ZWIERZĄT}

W obrębie różnorodnych pól znaczeniowych grupujących wyrazy jako źródła leksykalnych przezwisk, przybierających z czasem postać nazwisk, szczególne miejsce zajmują dwie klasy - nazwy roślin i nazwy zwierzat ${ }^{17}$.

Człowieka identyfikowano ze światem roślin i zwierząt, porównując cechy i zachowania ludzkie i zwierzęce, wartościując w ten sposób wygląd lub charakter identyfikowanej osoby. W zebranym materiale wynotowano 365 jednostek tego typu (21,5\% całości nazwisk odapelatywnych, które nie zawierają wykładników formalnych); nazwy z pola znaczeniowego rośliny $i$ ich części genetycznie motywujące nazwiska obejmują 151 jednostek; z pola zwierzęta i ich części ciała wywodzi się 214 jednostek.

$\mathrm{W}$ semantycznym polu nazwy roślin (a $\mathrm{w}$ ich obrębie nazwy: drzew, krzewów, chwastów i owoców) szczególnie interesująca jest fascynacja człowieka drzewami oraz ich częściami (ponad 60 nazwisk motywowano tymi nazwami). Upodobanie to wynikać mogło z ludowej wiary człowieka, że drzewa mają duszę i rozumieją ludzi ${ }^{18}$ (Simonides 1991: 185; por. też Lech 2004: 35), a ponadto - jak dodaje Danuta Lech-Kirstein: „drzewa zajmowały w świadomości miejscowej ludności szczególne miejsce, a przez swoje znaczenie poznawcze, użytkowe i magiczne były przez śląską ludność wyjątkowo pozytywnie wartościowane" (Lech-Kirstein 2015: 237). Ową fascynację drzewami potwierdzają nazwiska: Lipa (96) < lipa, Płonka (25) < płonka 'drzewo nieszczepione' oraz wiele form wywodzących się z gwar cieszyńskich, jak: Brzimek (2) < brzimek 'modrzew', Chojka (1) < chojka 'choinka', Jedliczka (6) < jedliczka 'jodełka', Lyska (4) < lyska < stp. leska 'leszczyna pospolita', Trześnia (2) < trześnia 'czereśnia' oraz z gwar śląskich, por.: Grabiec (18) < grabiec 'grab', Kalina (4) < kalina 'krzew i jego owoc', Tlołka (34) < tlałka 'spróchniałe,

17 Problematyka wartości ukrytych w nazwiskach odapelatywnych i wywodzących się $\mathrm{z}$ pola semantycznego rośliny i zwierzęta, była wielokrotnie podejmowana $\mathrm{w}$ wycinkowych ujęciach analitycznych (por. np.: Magda-Czekaj 2003; Sojka-Masztalerz 2010; Łobodzińska 2012; Pelcowa 2012; Lech-Kirstein 2015).

18 Przywoływane w dalszych częściach tekstu symbole nazw pochodzą ze Słownika symboli autorstwa W. Kopalińskiego (Kopaliński 1990). W słowniku tym drzewa symbolizują: wzrost, drabinę do nieba, jedność, wielkość, stałość, schronienie, zdrowie, płodność, wielowiekowość (Kopaliński 1990: 73-75). 
zbutwiałe drzewo' ${ }^{19}$. Przeniesienie tych apelatywów do przestrzeni onimiczej najczęściej konotuje skojarzenia związane ze wzrostem, tężyzną fizyczną oraz z istotnymi dla kultury regionu wartościami (por. znaczenie nazwy pospolitej sosna, która mogła symbolizować długowieczność, wytrzymałość, zwycięstwo, zdrowie).

Podobnie wyrazy mieszczące się w polu nazwy grzybów mogły określać metaforycznie osoby wysokie i/lub otyłe, osoby niskie i/lub szczupłe, por.: Biela (72) < biela 'grzyb bedłkowaty', Kozok (22) < gw. ciesz. kozok 'koźlarz grabowy', Szwam (1) < gw. śl. szwam 'grzyb modrzewiowy', Stonka (4) < gw. młp. słonka 'żółty grzybek jesienny', też 'ptak z bekasów'. Wyzyskując charakter metonimicznych przeniesien, przywołano też znaczenia roślin z innych pól znaczeniowych, por.: Cebula $(22)<$ cebula - ma oczy jak cebula; wyłupiaste, bardzo wypukłe, okrągłe; Groch (13) < groch i Cieczotka (1) < stp. cieczorka 'groch' - to osoba niska, krępa; Knol (3) $<$ śl. 'ziemniak' < niem. knolle - osoba otyła lub ograniczona umysłowo; Wika (2) < gw. Pom. Pd. 'bób' - niska, puszysta; Kalmus (1) < gw. gw. kasz. i gw. Pom. Pd. i kalamus 'tatarak' - wysoka i szczupła ${ }^{20}$. Wykorzystując ów mechanizm kreacyjny, eksponowano również cechy psychiczne nosicieli, por.: Kapusta (18) < kapusta i Chwastek (104) < gw. wlkp. chwastek 'kapusta niedorodna' mogły charakteryzować osobę ograniczoną, zaś Poksziwa (1) < gw. ciesz. poksziwa - osobę dokuczliwą.

Zawarte w podstawach nazwisk nazwy kwiatów mogły symbolizować: tajemnicę, harmonię, narodziny, szczęście i bezpieczeństwo. Pole znaczeniowe kwiaty $\mathrm{w}$ większości reprezentują gatunki ogrodowe, por.:

19 W identyczny sposób dokonano przeniesień nazw części drzew i krzewów do płaszczyzny onimicznej, por.: Stark (8) < stp. stark 'gałąź', też 'krzak', Chrostek (27) < gw. ciesz. chrostek 'niski krzak, krzewinka', też 'źle zwinięta w główkę kapusta', Habina (2) < gw. śl. habina 'gałązka', Kotula (192) < gw. ciesz. kotula 'witka z cienkich gałązek świerkowych lub korzeni do umocowania krząseł pomiędzy wbitymi kołami w sałdaszu, też mosiężna spinka', Karkoszka (49) < gw. ciesz. karkoszka 'odrąbana, niezbyt gruba sucha gałąź', Kłoda (117) < stp. kłoda 'kloc drewniany, pień, duża i gruba belka; słup'.

20 Opisowi wyglądu zewnętrznego człowieka oraz ujawnieniu jego cech posłużyły też nazwy części roślin, por.: Korzonek (17) < korzonek - człowiek niski, zgarbiony; Głąb (7) $<$ głab 'zgrubiała łodyga' i Głąik (2) 'pień kapusty' - konotują ograniczoność umysłową, niezdarność, zaś Peczka (2) < stp. pecka 'pestka', też 'twarde jądro w owocu' - stałość, silny charakter. Nazwy owoców, symbolizujące dostatek, posłużyły określeniu postury człowieka (por. Dynia (12) < dynia i Korbas (31) < stp. korbas 'dynia', Gruszka (73) < gruszka), zaś nazwy wybranych gatunków - mogły konotować zestaw innych kulturowo utrwalonych wartości, por.: Figa (1) - mogła symbolizować obfitość, płodność, dorodność, plon, długowieczność, prawdę, Śliwka (145) < śliwka i Szwestka (1) < gw. śl. szwestka 'odmiana śliwki', oraz Gogótka (23) < gw. ciesz. i gw. śl. < stp. gogótka 'owoc na drzewie świeżo zawiązany'dorodność i dostatek. 
Cyprys (16) < cyprys, < gw. ciesz.: Georginia (1) 'dalia', Lilija (1) < stp. lilija 'lilia'. Nazwy te, mogły konotować inne cechy człowieka, np.: lilia chwałę, wyborność, majestat i smutek, zaś cyprys - troskę i trwałość.

Nazwy chwastów (traw) i roślin trujących jako genetyczne podłoże nazwisk w szczególny sposób posłużyły wyrażaniu negatywnych właściwości człowieka i w sposób metaforyczny oceniały ludzi jako gorszych od osoby ich nazywającej, por.: Stokłosa $(54)<$ stokłosa 'roślina trawiasta', Kostrzewa (1) < stp. kostrzewa 'chwast zbożowy', Supik (133) < stp. supik 'szalej jadowity, trująca roślina z rodziny sekułowatych', Szustek (2) < gw. ciesz. szustek 'chwast zbożowy', Opioł (5) < gw. śl. i gw. ciesz. opioł 'chwast wyrwany przy paleniu'.

Motywujące zbiór 224 nazwisk nazwy zwierząt, w podobny sposób jak nazwy roślin, stały się punktem wyjścia porównań cech i zachowań ludzkich do zwierząt oraz do ich części ciała.

Najliczniejszą grupę nazw konotujących troskę rodzicielską i wolność, na podstawie których stworzono porównania ludzi do świata zwierząt, stanowią nazwy ptaków ${ }^{21}$ (por. Ptoszek (80) < gw. śl. ptoszek 'ptaszek'). Nazwy wybranych gatunków ptaków użyte jako podstawy apelatywne nazwisk ze względu na ich kulturowo-regionalne asocjacje, mogły być kojarzone z konkretnymi cechami człowieka. Nazwiska te, tworzące zbiór synonimów dialektalnych, których cechy konotacyjne reprezentują określoną jakość semantyczną, ilustrują następujące przykłady: Czap $(8)<$ gw. ciesz. czap (bohem.) < czes. čap 'bocian'; Bocek (86) < gw. młp. bocek 'bocian'; Czapla (28) < czapla - czujna, ciekawa, ostrożna, Gołąb (1) < gołąb, Stawiok (1) < gw. śl. < stawiok 'rasa gołębia' - pokorny, mądry, łagodny, spokojny, też pobożny; Jaskółka (10) < jaskółka, Lasztuwka (1) < gw. ciesz. lasztuwka < czes. vlaštovka 'jaskółka' - wolna, pracowita; Kukuczka (9) < gw. ciesz. kukuczka 'kukułka' - podstępna, egoistyczna, tchórzliwa, samotna; Łabędź (7) < tabędź - piękny, szlachetny, samotny, wierny; Pelikan (3) < pelikan - towarzyski, butny, żarłoczny; Sowa (1) < sowa i Lelek (1) $<$ gw. maz. lelek - samotna, czujna, mądra; Słowik (94) < słowik - wolny, czujny, smutny, tęskniący; Sroka (1) < sroka - gadatliwa, uparta, naiwna; Sikora $(848)<$ sikora i Bargiel $(1)<$ gw. śl. i gw. młp. bargiel 'gatunek sikory' - wesoła; Sojka (108) < sojka 'ptak wróblowaty', Wróbel $(30)<$ wróbel, Czeczotka $(65)<$ gw. młp. czeczotka 'ptak z rodziny wróblowatych' i Wró-

21 Część z nich charakteryzuje wysoka frekwencja, por.: Czyż (156), Drózd (49), Gawron (68), Kania (126), Pustówka (281), Raszka (349). 
blik (1) < gw. śl. wróblik 'wróbel' - czujność, płochliwość, lekkomyślność oraz skromność.

$\mathrm{W}$ obrębie nazwisk odapelatywnych $\mathrm{z}$ semantycznego pola ptaki warte uwagi są te, w podstawy których wpisano gwarowe określenia ptaków udomowionych z rodziny kurowatych. Formy te generują ekspresywne znaczenia charakteryzujące ludzi, por.: Kura (1) < kura - lekkomyślna, gospodarna, rodzinna, Kogut (3) < kogut - porywczy, waleczny, pracowity, apodyktyczny oraz warianty gwarowe nazywające koguta: Kohutek (56) < gw. ciesz. kohótek, Kokotek (202) < gw. ciesz. kokotek - 'młody kogut', Kurdziel (16) < gw. ciesz. kurdziel 'kogut, który nie przejawia popędu seksualnego' oraz Kurzel (1) < gw. śl. kurzel i Kokot (9) < gw. ciesz. i gw. śl. < stp. kokot22 'kogut'.

Źródłem leksykalnych przezwisk z grupy znaczeniowej zwierzęta mogły też być nazwy zawierające się $\mathrm{w}$ podrzędnym polu ryby. W polu tym znalazły się nazwy określające ryby pochodzące $\mathrm{z}$ rodziny karpiowatych, por.: Bazgier (1), Bazgierz (1) < bazgier 'jazgarz, nieduża ryba z rodziny okoniowatych', Karaś $(1)<$ gw. śl. karaś i Karas $(48)<$ gw. śl. karas 'ryba z rodziny karpiowatych', Parma (3) < gw. ciesz. parma 'brzana, ryba z rodziny karpiowatych', Śliż (54) < śliż 'mała rybka z rodziny karpiowatych', symbolizujące $w$ kulturze życie, wiarę oraz niezdarność i chciwość.

W polu semantycznym zwierzęta, będącym bazą wyjściową metafor animalistycznych, dominują nazwy konotujące cechy o wysokim stopniu utrwalenia, por.: kon - wytrzymały, silny, pracowity, pies - wierny, przyjazny, odważny, owca - lękliwa, łagodna, bierna, uparta, naiwna. Nazwiska te mogły też przywoływać liczne związki i zależności między ludnością wiejską a zwierzętami23, por.: Woźniak (5) < woźniak 'koń pociągowy', Siwek (1) < siwek 'koń siwy', Wilczek (128) < wilczek 'koń maści wilczastej', Fuks (3) < gw. ciesz., gw. śl., gw. maz. i gw. Pom. Pd. fuks 'koń

22 Por. też nazwy innych gatunków ptaków udomowionych, które wpisano w podstawy nazwisk omawianego typu (por.: Puta $(2)<$ gw. śl., gw. maz., gw. kasz. i gw. Pom. Pd. puta 'indyczka', Trusiok (1) < gw. ciesz. i gw. śl. trusiok 'indyk') określające takie cechy ludzkie, jak: energiczność i impulsywność), zaś Kosiel (2) < gw. śl. kosiel 'gęss' - gadatliwość, lekkomyślność, ograniczoność, tchórzliwość.

23 H. Pelcowa pisze, że „,[...] w wypadku najstarszych mieszkańców wsi - użytkowników polszczyzny gwarowej - obraz konia jest pełniejszy niż w świetle danych leksykograficznych, ale nie jest jednoznaczny, bo na zbiorową językową konceptualizację nakładają się oceny i odczucia osobiste, a każdy z interlokutorów przekazuje swój sposób postrzegania i wartościowania konia jako nie tylko obiektu pracy, lecz cząstki otaczającej przyrody, a nawet uczestnika życia rodzinnego, w tym jego sfery ekonomicznej" (Pelcowa 2012: 469). 
maści kasztanowatej z jasną grzywą i ogonem', Krak $(1)<$ gw. Pom. Pd. krak 'szkapa', Mera (1) < gw. kasz. mera 'stary, lichy kon', Chlebus (44) < gw. śl. chlebus 'o psie łagodnym, potulnym, który nie szczeka na obcych', też 'nierób, obibok', Kondys (14) < kondys 'pies nierasowy, kundel', Łabaj (33) < stp. łabaj 'wielki pies', Muras (49) < gw. młp. muras 'pies czarny', też 'murarz', Jarka (6) < gw. ciesz. jarka 'roczna owieczka', Murys (14) < gw. ciesz. murys 'owca mająca ciemne plamki na pysku', też < gw. ciesz. i gw. śl. 'roczna owieczka', Korn (3) < gw. śl. korn 'żytniówka, owca rogata'.

Innymi cechami, jakie wytykali członkom mikrowspólnoty mieszkańcy Śląska Cieszyńskiego, były: głupota i naiwność (por.: Cielok (1) $<$ gw. ciesz. cielok 'cielę', Rojek (9) < gw. śl., gw. maz., gw. młp. i gw. wlkp. rojek 'wół mały rasy góralskiej'), obżarstwo i skąpstwo (por.: Babuciek (2) $<$ gw. ciesz. buciek 'mały prosiaczek', Jeż (18) < jeż, Pruszek $(1)<$ gw. kasz. pruszek 'prosię, warchlak'), niedojrzałość (por.: Habel (2) < nowe dialekty mieszane habel 'cielę odsadzone od krowy'), nieokrzesanie, impulsywność i wybuchowość (por.: Dzik (19) < dzik, Goryl $(45)<$ goryl), przebiegłość, pochlebstwo i obłudę (por.: Lis (1) < lis, Liszka (61) < liszka 'lis samica', Żmijka (1) < żmijka 'gatunek lisa'), flegmatyczność (por. Ślimak (2) < ślimak); pasożytnictwo (por. Pilch (81) < pilch 'zwierzę należące do gryzoni'), strachliwość (por. Zając (50) < zając), chytrość, fałszywość i lenistwo (por. Kot $(4)<$ kot, Kocur $(140)<$ gw. ciesz. i gw. śl. kocur 'kot').

Negatywne skojarzenia ewokują też zawarte w nazwiskach podstawy wywodzące się z pola semantycznego nazwy płazów, gadów i owadów (por.: Chrzasscz (2) < chrząszcz, Ćmiel (4) < gw. śl. ćmiel 'trzmiel', Kijanka (1) < kijanka, Mucha (8) < mucha, Pająk (8) < pająk, Skoczek (1) < gw. ciesz. skoczek 'drobny, skaczący owad (szkodnik roślin)', Szczypka (15) < gw. ciesz. szczypka 'szczypawka; skorek (owad)', Klyszcz (25) < gw. śl. klyszcz 'kleszcz' czy Żmija (190) < żmija, charakteryzujące ludzi nadętych, próżnych, uszczypliwych, dokuczliwych i podstępnych.

Ekspresywne konotacje deprecjonujące człowieka niosą też zawarte w nazwiskach nazwy eksponujące niedołęstwo lub brzydotę ${ }^{24}$, do kreacji których wyzyskano wyrazy używane już w staropolszczyźnie, por.:

24 Brzydotę ludzką wytykano też przy pomocy nazw części ciała zwierząt (zwłaszcza tych o szczególnym ładunku ekspresywnym), por.: Boch $(1)<$ stp. boch 'tułów obłupionego ze skóry bydlęcia', Puzon (1) < puzon 'brzuch zwierzęcy', Ryj (1) < ryj i odpowiedniki gwarowe tego określenia: Hachuła (2) < gw. młp. chachuła 'pysk, morda', Tutka (1) < gw. młp. tutka 'pysk krowy', Kruszka (1) < gw. ciesz. kruszka 'cielęce żołądki i jelita', też < gw. śl. 'grusza', Strzałka (9) < gw. młp. strzałka 'część nogi końskiej tuż przy kopycie'. 
Gomola (29) < gomoła 'krowa bez rogów', Gomuła (1) 'sarna bez rogów', Zuber (2) < zuber 'stara krowa nie nadająca się do hodowli'.

Niedomaganie ludzi symbolizują zapisane $\mathrm{w}$ podstawach nazwisk nazwy chorób zwierzęcych, por.: Czerwionka (2) < gw. ciesz. czerwiónka 'choroba świń', w gw. kasz. i gw. Pom. Pd. czerwionka 'krowa czerwona', Koler (6) < gw. śl. (z niem. koller) 'choroba mózgu', Krop (52) < gw. śl. krop 'choroba krowy, świni, powstała wskutek jedzenia tłustej paszy', też 'kropla'.

Opisywaną grupę (b) Nazwisk pochodzacych od nazw roślin i zwierząt motywowały nazwy animalistyczne konotujące pozytywne skojarzenia człowieka z światem zwierząt (warto zwrócić uwagę na wysoką frekwencję większości z nich), por.: Mrowiec (16) < gw. ciesz. i gw. śl. mrowiec 'mrówka' oraz Pszczótka (192) < pszczótka, które mogły określać człowieka pracowitego, gospodarnego, bezinteresownego, troskliwego i porządkowego ${ }^{25}$.

Zamykając interpretację nazwisk charakteryzujących człowieka przy użyciu metafor animalistycznych, warto zwrócić uwagę na to, że zawarte $\mathrm{w}$ ich podstawach nazwy pospolite mogły przywoływać podobne skojarzenia jak te zawarte w nazwiskach charakteryzujących człowieka w sposób bezpośredni z grupy (a) - prymarnie sprowadzające się do aktu negatywnej oceny nazywanej osoby - wytykania mu różnych wad, i tylko okazjonalnie - eksponowania jego zalet.

\section{NAZWISKA POCHODZĄCE OD NAZW ZJAWISK PRZYRODNICZYCH, ATMOSFERYCZNYCH I NAZW TEMPORALNYCH}

Immanentną funkcję wśród zebranego zbioru odgrywają 32 nazwiska powstałe od nazw zjawisk przyrodniczych, atmosferycznych $i$ temporalnych. W kulturze ludowej nazwy te mogły dookreślać czasoprzestrzeń, porządkować wiedzę człowieka o świecie, a w wypadku zjawisk atmosferycznych - uzasadniać współzależność człowieka od przyrody. Przeniesienia nazw mieszczących się $\mathrm{w}$ tym zakresie znaczeniowym $\mathrm{z}$ apelatywnej do proprialnej sfery języka przybierały postać metafor.

25 Por. też inne przykłady: Jeleń (110) < jeleń, podobnie jak Sarna (1) i Wiewiórka (21) mogły określać człowieka szybkiego, ruchliwego, zwinnego; inne: Bujok $(46)<$ gw. ciesz. bujok 'byk', Joniec (1) < gw. młp. joniec 'byczek' - charakteryzować osoby waleczne. 
Określenia czasowe wyzyskane jako podłoże nazwisk najczęściej odwoływały się do wieku osób, por.: nazwisko Rok (1), które mogło symbolizować młodość, zaś Wiek (1) - starość i doświadczenie.

Zawarte $\mathrm{w}$ podstawach nazwisk nazwy pór dnia i pór roku oraz określenia temperatury kojarzono $\mathrm{z}$ temperamentem, charakterem i usposobieniem człowieka. Nazwiska motywowane wyrazami wywodzącymi się z gwar cieszyńskich, por.: Hyc (1) < hyc 'ciepło, żar', Parota $(1)<p a-$ rota 'parność' czy Skwara (3) < skwara 'upał' mogły nazywać człowieka energicznego, nadpobudliwego i zmiennego ${ }^{26}$. Skojarzenia z porą dnia, jak: Rosa (3) < rosa, a w gw. młp. 'pot', Zora (1) < gw. kasz. zora 'zorza', mogły symbolizować urodzaj, smutek i przemijanie. Synonimiczne określenia dialektalne wiatru jako komponentu podstawy nazwisk mogły posłużyć do opisu człowieka gwałtownego, porywczego, srogiego, silnego, twardego oraz niezdecydowanego i nieprzewidywalnego, por.: Halny (1) $<$ halny, Wieja (13) < gw. śl., gw. wlkp. i gw. kasz. wieja 'wichura, zawierucha, zadymka', Wicher (4) < wicher 'silny, gwałtowny wiatr', Wichura (1) $<$ wichura, Wija (3) < gw. kasz. i gw. Pom. Pd. wija 'ostry wiatr, często ze śniegiem; zawieja, zadymka' oraz Szturm (3) < gw. śl., gw. maz., gw. Pom. Pd. 'sztorm, burza'.

Nazwy pór roku, miesięcy, dni tygodnia oraz nazwy liczb jako nieliczne podstawy nazwisk (por.: Jary (1) < stp. jary 'urodzony wiosną' i Maj (20) $<$ maj oraz Piątek (5) < piątek i Sobota $(1)<$ sobota) mogły konotować pozytywne wartości, jak: pogoda ducha i szczęście, zaś nazwisko Szosty (1) < szósty [alternacja ó : o] < szósty - stałość, harmonię, wolność i równowagę.

\section{NAZWISKA OD NAZW DŹWIĘKONAŚLADOWCZYCH}

Użyte $\mathrm{w}$ trakcie onimicznych przeniesień wyrazy dźwiękonaśladowcze motywowały kilka nazwisk, por.: Hopsa (1) < hopsa! (wykrzyknik), Hosa (2) < gw. śl. hosa (wykrzyknik), Puk (1) < puk (dźwiękonaśladowcze),

\footnotetext{
26 Podobne asocjacje uzyskano, używając nazw zjawisk atmosferycznych oraz ich rezultatów (por.: Mroczek (1) < gw. śl. i gw. młp. mroczek 'chmura' - mogły służyć do charakterystyki człowieka groźnego, gniewnego, pochmurnego), pozostałe zaś, jak: Kałuża (203) $<$ kałuża 'błoto', Pluta (1) < stp. pluta 'długotrwały deszcz, słota', też < gw. wlkp., gw. kasz. i gw. Pom Pd. 'kałuża, bajoro', Smusz (2) < gw. śl. smurz 'mgła', Psota (3) < gw. śl. i gw. młp. psota 'niepogoda, słota', też < stp. 'figiel' - wyzyskano do określeń człowieka podstępnego, zmiennego, nieprzyjemnego).
} 
Puff (5) < puf (wykrzyknik naśladujący sapanie parowozu), też 'tapicerski taboret' czy Bzyk (1) (dźwięk wydawany przez owady). Zawarte w nazwiskach określenia prymarnie ekspresywne mogły nie tylko charakteryzować temperament nazywanych nimi ludzi, ale również przywoływać nadużywane przez człowieka wyrazy czy powiedzenia.

\section{WNIOSKI}

Podjęta $\mathrm{w}$ artykule problematyka wartości konotowanych przez podstawy apelatywne nazwisk mieszkańców południowego Śląska potwierdza wyniki innych regionalnych badań, na podstawie których stwierdzono, że „dezaprobata w nazwie pojawiała się o wiele częściej niż pochwała, zawarta w określeniach melioratywnych" (Naruszewicz-Duchlińska 2008: 317; por. też: Abramowicz 2006: 26; Lech 2004: 29).

Zgromadzony zasób nazwisk odapelatywnych obrazuje kulturę ludności żyjącej na Śląsku - sposób postrzegania i wartościowania rzeczywistości za pomocą cech konotacyjnych, które reprezentują określoną jakość semantyczną i są ewokowane przez nazwy pospolite (por.: Lech 2003: 217-230; Lech 2004: 30).

W obrębie ujawnianych mechanizmów nazewniczych warty uwagi jest fakt współistnienia obok siebie nazw synonimicznych (kalk) pochodzących z różnych odmian gwarowych języka, por. np. nazwiska z pola znaczeniowego wiatr (grupa c) oraz z pola semantycznego nazwy ptaków (grupa b). Owe zjawiska „wskazują na rozbudowanie pojęcia, a przez to na jego wysoką rangę w systemie pojęciowym" (Kaleta 2003: 22) oraz obrazują regionalne i ogólnopolskie tendencje do tworzenia określonych modeli nazewniczych.

Będąca przedmiotem artykułu analiza nazwisk odapelatywnych mieszkańców południowego Śląska nie wyczerpuje całokształtu zagadnienia. Jej wycinkowość skłania do kontynuacji badań nazwisk cieszyńskich opisywanego typu, a w rezultacie - rekonstrukcji językowo-kulturowego obrazu świata przez nie utrwalonego.

\section{WYKAZ SKRÓTÓW}

$\begin{array}{ll}\text { bohem. } & - \text { bohemizacja } \\ \text { bułg. } & - \text { bułgarski } \\ \text { czes. } & - \text { czeski }\end{array}$

gw. ciesz. - gwary cieszyńskie gw. góral. - gwary góralskie gw. kasz. - gwary kaszubskie 


$$
\begin{array}{ll}
\text { gw. maz. } & - \text { gwary mazowieckie } \\
\text { gw. młp. } & - \text { gwary małopolskie } \\
\text { gw. Pom. Pd. } & - \text { gwary Pomorza } \\
& \text { Południowego } \\
\text { gw. śl. } & - \text { gwary śląskie } \\
\text { gw. wlkp. } & - \text { gwary wielkopolskie }
\end{array}
$$

$$
\begin{array}{ll}
\text { niem. } & - \text { niemiecki } \\
\text { pejor. } & - \text { pejoratywnie } \\
\text { pogardl. } & - \text { pogardliwie } \\
\text { przen. } & - \text { przenośnie } \\
\text { stp. } & - \text { staropolski } \\
< & - \text { pochodzenie }
\end{array}
$$

\section{BIBLIOGRAFIA}

\section{SŁOWNIKI}

Brückner A., 1985, Stownik etymologiczny języka polskiego, Warszawa.

Czajkowski A., Czajkowska I., Klukowski A., Klukowska D. (red.), 1996, Słownik gwary śląskiej, wyd. 2, Katowice.

Cząstka-Szymon B., Ludwig J., Synowiec H. (red.), 2000, Mały słownik gwary Górnego Śląska, cz. 1, wyd. 2, Katowice.

Golec J., 1991, Cieszyński słownik gwarowy, Cieszyn.

Gruchmanowa M., Walczak B. (red.), 1999, Stownik gwary miejskiej Poznania, Poznań.

Karłowicz J. (red.), 1900-1911, Słownik gwar polskich, t. 1-6, Kraków.

Karłowicz J., Kryński A., Niedźwiedzki W. (red.), 1900-1927, Słownik warszawski (Słownik języka polskiego), t. 1-8, Warszawa.

Kopaliński W., 1990, Stownik symboli, Warszawa.

Kowalik-Kaleta Z., Dacewicz L., Raszewska-Żurek B. (red.), 2007, Stownik najstarszych nazwisk polskich. Pochodzenie językowe (XII-XV wiek), t. 1, Warszawa.

Krasnowolski A. (oprac.), 1914, Stownik staropolski, t. 1, Warszawa.

Linde, S. B., 1807-1814, Słownik języka polskiego, t. 1-6, Lwów.

Milerski W., 2009, Zachodniocieszyński słownik gwarowy, Czeski Cieszyn.

Milerski W., 1996, Nazwiska cieszyńskie, Warszawa.

Perzowa H., Kołodziejczykowa D. (red.), 2000, Słownik gwar Ostródzkiego Warmii i Mazur, t. 4: $L-N$, Warszawa-Kraków.

Perzowa H., Kołodziejczykowa D. (red.), 2006, Słownik gwar Ostródzkiego Warmii i Mazur, t. 5: O-Ó, Warszawa-Kraków.

Rospond S., 1967, Słownik nazwisk śląskich, cz. 1: A-F, Wrocław-Warszawa-Kraków.

Rospond S., 1973, Słownik nazwisk śląskich, cz. 2: G-K, Wrocław-Warszawa-Kraków-Gdańsk.

Rymut K., 1991, Nazwiska Polaków, Wrocław-Warszawa-Kraków.

Rymut K., 1992-1994, Słownik nazwisk współcześnie w Polsce używanych, t. 1-10, Kraków. 
Sarnowska-Giefing I. (red.), 2011, Słownik nazwisk mieszkańców Poznania XVI-XVIII wieku, t. 1: A-F, Poznań.

Sławski F., 1952-1975, Słownik etymologiczny języka polskiego, t. 1-5, Kraków.

Stamirowska Z., Perzowa H. (red.), 1993, Słownik gwar Ostródzkiego Warmii i Mazur, t. 3: H-K, Warszawa-Kraków.

Tomczak L. , 2003, Słownik odapelatywnych nazwisk Polaków, Wrocław.

Urbańczyk S. (red.), 1953-2002, Słownik staropolski PAN, t. 1-11, Kraków.

Wietrzyk A. (red.), 2011, Słownik gwary Pogórzan (z okolicy Gorlic), Gorlice.

Wronicz J. (red.), 2010, Słownik gwarowy Śląska Cieszyńskiego, wyd. 2, Ustroń.

Wronicz J., 2010, Mały słownik gwar polskich, Kraków.

Zborowski J. (red.), 2009, Słownik gwary Zakopanego i okolic, Zakopane-Kraków.

\section{WYKAZ WYKORZYSTANEJ LITERATURY PRZEDMIOTOWEJ}

Abramowicz Z., 2006, Kulturowy aspekt onimizacji, w: Onimizacja i apelatywizacja, red. Z. Abramowicz, E. Bogdanowicz, Białystok, s. 23-29.

Apresjan J. D., 2000, Semantyka leksykalna. Synonimiczne środki językowe, przeł. Z. Kozłowska A. Markowski, Wrocław-Warszawa-Kraków.

Bartmiński J., 2001, Styl potoczny, w: Współczesny język polski, red. J. Bartmiński, Lublin.

Bogdanowicz E., 2010, Konotacje wartościujące nazw własnych, w: Nazwy własne a społeczeństwo, t. 1: Zagadnienia teoretyczne i metodologiczne. Antroponimia, red. R. Łobodzińska, Łask, s. 115-125.

Borek H., Szumska W., 1976, Nazwiska mieszkańców Bytomia od końca XVI wieku do roku 1740. Studium nazewnicze i społeczno-narodowościowe, Warszawa-Wrocław.

Dacewicz L., 2003, Z historii nazwisk na polsko-wschodniosłowiańskim pograniczu kulturowym (wiek XVI-XVIII), w: Nazwy własne a kultura. Polska i inne kraje słowiańskie, red. Z. Kaleta, Warszawa, s. 11-19.

Górny H., 2003, Badania apelatywów antroponimicznych metoda pól semantycznych, w: Metodologia badań onomastycznych, red. M. Biolik, Olsztyn, s. 231-239.

Kaleta Z., 2003, Świat wartości w staropolskich odapelatywnych nazwach osób, w: Nazwy własne a kultura. Polska i inne kraje słowiańskie, red. Z. Kaleta, Warszawa, s. $21-48$.

Lech D., 2003, Nazwiska apelatywne a kultura regionu (na przykładzie Ślaska Opolskiego), w: Metodologia badań onomastycznych, red. M. Biolik, Olsztyn, s. 217-230.

Lech D., 2004, Nazwy osobowe dziewiętnastowiecznych mieszkańców Opola (ze słownikiem etymologicznym nazwisk), Opole.

Lech-Kirstein D., 2015, Nazwy drzew w śląskiej toponimii, "Onomastica” LIX, s. 223-239. 
Łobodzińska R., 2012, Średniopolskie nazwiska ślaskie motywowane nazwami roślin, $\mathrm{w}$ : W komunikacyjnej przestrzeni nazw własnych i pospolitych. Księga jubileuszowa dedykowana Profesorowi Robertowi Mrózkowi, red. I. Łuc, M. Pogłódek, Katowice, s. 237-242.

Magda-Czekaj M., 2003, Imiona a nazwy roślin. Onimizacja i apelatywizacja, „Onomastica" XLVIII, s. 209-223.

Matusiak I., 2007, Rudy jest fałszywy - o kilku stereotypach utrwalonych w nazwiskach (na przykładzie nazwisk mieszkańców komornictwa jeziorańskiego na Warmii w XVI-XVIII w.), w: Studia poświęcone Profesorowi Bohdanowi Głuszczakowi, red. I. Grzesiak, A. Naruszewicz-Duchlińska, A. Staniszewski, Olsztyn, s. 379-389.

Matusiak-Kempa I., 2010, Wartościowanie estetyczne utrwalone w nazwiskach polskich i niemieckich na Warmii. Rekonesans, w: Mnohotvárnost a specifičnost onomastyki. IV česká onomastická konference 15.-17. zárĭ 2009. Sborník přispěvkü, red. J. David, M. Čornejová, M. Harvalík, Ostrava-Praha, s. 355-364.

Monteiro-Plantin R. S., 2011, Gastronomismos linguísticos: um olhar sobre fraseologia e cultura, w: Uma (re)visão da teoria e da pesquisa fraseológicas, red. M. L. Ortiz Alvarez, E. Huelva Unternbäumen, Campinas, s. 249-275.

Naruszewicz-Duchlińska A., 2008, Nazwiska mieszkańców komornictwa lidzbarskiego (1500-1772 r., Olsztyn.

Pelcowa H., 2012, Koń w wiejskiej rzeczywistości językowej, w: W komunikacyjnej przestrzeni nazw własnych i pospolitych. Księga jubileuszowa dedykowana Profesorowi Robertowi Mrózkowi, red. I. Łuc, M. Pogłódek, Katowice, s. 463-470.

Puzynina J., 1992, Język wartości, Warszawa.

Pysiewicz-Jędrusik R., Pustelnik A., Konopska B., 1998, Granica Śląska w czasie i przestrzeni. Śląsk na dawnej mapie. Obraz Sudetów w dawnej kartografii, Wrocław.

Raszewska-Klimas A., 2015, Elementy mody i ubioru w historycznych odapelatywnych nazwiskach Polaków. Wykaz antroponimów, w: Kulturowy obraz mód społecznych, red. J. Bujak-Lechowicz, Szczecin, s. 173-189.

Rutkowski M., 2005, Kilka uwag o konwencjach opisu wartości semantycznej nazw własnych, "Onomastica” L, s. 99-110.

Rzetelska-Feleszko E., 2006, Czy nazwy własne maja wartość?, w: Onimizacja i apelatywizacja, red. Z. Abramowicz, E. Bogdanowicz, Białystok, s. 591-599.

Simonides D., 1991, Ludowa wizja świata, w: Kultura ludowa śląskiej ludności rodzimej, red. D. Simonides, Wrocław-Warszawa, s. 7-27.

Sojka-Masztalerz H., 2010, Wspótczesne nazwiska mieszkańców Wrocławia i Lwowa majace w swych podstawach nazwy gatunkowe ptaków, w: Nazwy własne a społeczeństwo, t. 1: Zagadnienia teoretyczne $i$ metodologiczne. Antroponimia, red. R. Łobodzińska, Łask, s. 377-394.

Tokarski R., 2001a, Językowy obraz świata - przybliżenia, w: Wspótczesny język polski, red. J. Bartmiński, Lublin, s. 364-369. 
Tokarski R., 1998, Konotacja jako składnik treści słowa, w: Konotacja, red. J. Bartmiński, Lublin, s. 35-54.

Tokarski R., 2001b, Słownictwo jako interpretacja świata, w: Współczesny język polski, red. J. Bartmiński, Lublin, s. 343-370.

Whorf B. L., 1982, Język, myśl i rzeczywistość, przeł. T. Hołówka, Warszawa.

Wyderka B., 2005, Odmiany regionalne czy regiony językowe?, „Biuletyn Polskiego Towarzystwa Językoznawczego", z. LXI, Kraków, s. 57-66.

\title{
EVALUATIVE CONNOTATIONS IN APPELATIVE FORM SURNAMES OF THE INHABITANTS OF ŚLĄSK CIESZYŃSKI IN 19th CENTURY
}

\begin{abstract}
Summary
In the article native appelative form surnames of the inhabitants of Sląsk Cieszyński taken from 19th century archives were described. Those surnames without derivative indicators were the basis for the search for semantic connotations (cultural and regional) present in appelative roots. While analysing the collected data the author referred to axiological semantics and considered the sociolinguistic aspects of name-giving. Moreover, references to statistical research were made.
\end{abstract}

Key words: appelative form surname, value, connotation, Śląsk Cieszyński 